\title{
ENVIRONMENTAL CHANGES RECORDED IN SOME IMPORTANT PERI- AND META-CARPATHIAN PALAEOLITHIC SITES AND THEIR CHRONOSTRATIGRAPHY
}

\author{
MARIA ŁANCZONT* AND TERESA MADEYSKA** \\ *Department of Geoecology and Palaeogeography, Maria Curie-Skłodowska University, \\ Al. Kraśnicka 2 cd, 20-718 Lublin, Poland \\ E-mail: lanczont@poczta.umcs.lublin.pl \\ **Institute of Geological Sciences, Polish Academy of Sciences, \\ Twarda 51/55, 00-818 Warszawa, Poland \\ E-mail: tmadeysk@twarda.pan.pl
}

\begin{abstract}
The actual state of research on natural aspects of history of prehistoric settlement in the peri- and meta-Carpathian zones based on investigations of important multilayer Palaeolithic sites is presented. Traces of Palaeolithic people stay, in the form of cultural layers, are found at sites representing three types of sedimentary environment, i.e. cave (Biśnik cave in the Częstochowa Upland, Obłazowa cave in the Podhale region), loess (Galich and Yezupil in the Galich Prydnistrov'ia region, Velykyj Glybochok in the Podil'ia region), and travertine (Hôrka-Ondrej and other sites in the Spiš region).

Different geological methods were used in investigations of separate site types, and the obtained results are complementary and verify one another. Their comparison enables us to obtain multilevel picture of palaeoenvironmental changes. Correlation of deposit sections in these different types of sites is based on climatically controlled sequences of environmental changes. Chronostratigraphic extents of individual cultural units from selected sites and their correlation are based on oxygen-isotope stratigraphy. The extents are presented as continuous despite the fact that cultural layers represent mostly traces of short-lasting settlement.

Investigations of Palaeolithic sites in the Podil'ia and Prydnistrov'ia regions proved that settlement existed from the penultimate interglacial to the end of the last glacial (MOIS 7-2). Materials from the Biśnik cave represent similar period but there are premises that Middle Palaeolithic settlement started earlier.
\end{abstract}

Key words: Palaeolithic chronology, cave sites, loess sites, travertine sites, palaeoenvironment, Poland, Ukraine

\section{INTRODUCTION}

Geological and palaeontological investigations of Palaeolithic sites are the basis for reconstruction of environment and stratigraphic position of individual cultural layers, and thus chronology of cultural changes. Several important, multilayer Palaeolithic sites occurring in the area situated to the north and north-east of the Carpathians (Poland, Ukraine), have been examined in the last decades and brought about new information about the prehistoric settlement. These sites are irregularly scattered in the vast foreland zone of the Outer Carpathians, i.e. mountain foothills and submontane basins (peri-Carpathian zone) together with the meta-Carpathian uplands adjoining 


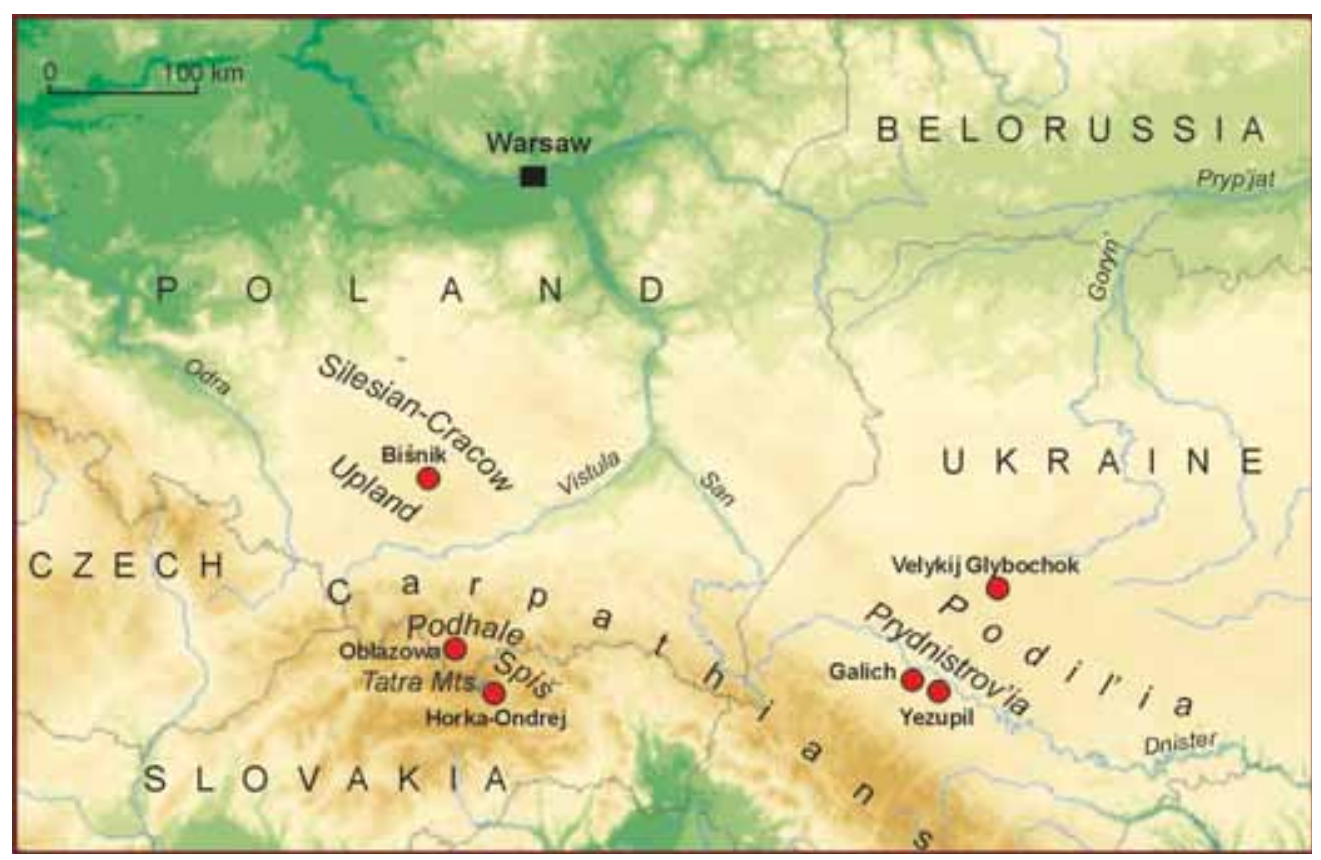

Figure 1. Location of the studied sites

from the north. The sites are associated with the following geographical regions: Podil'ia, East Carpathian Foreland, and Silesian-Cracow Upland. We also include into this set another important site - Obłazowa care situated in the Podhale region, and travertine sites situated to the south of the Tatra Mountains (Fig. 1).

Traces of Palaeolithic people stay, in the form of cultural layers, are found in different deposits and different morphological situations. Cave sites prevail in the western, Polish part of the above presented area, and loess sites - in the eastern, Ukrainian part.

Correlation of these different types of sites is based on few dating results and climatically controlled sequences of environmental changes, which are reconstructed using different methods. Information about natural environment obtained for these two types of sites complement each other. Correlations of different archaeological sites based on their cultural interpretation are often difficult and dubious due to the differences in classification of cultural materials used by archaeologists. The authors hope that information about palaeoenvironmental changes and comparison of stratigraphic positions of individual cultural layers in different sites will be useful in specifying time-frames of cultures, at least great cultural units, in different regions of the periand meta-Carpathian area.

\section{STUDY AREA}

The study area is a part of the continental bridge between the Baltic and Black Sea. A distinct orographic barrier is absent because the European watershed between the San River (tributary of the Vistula River) and Dnister River (flowing across the East Carpathian Foreland) is extremely low and indistinct, which is the feature inherited from the Mesopleistocene stage of relief evolution (Bogucki et al., 1999). Due to such morphology, this area is affected both by maritime (Atlantic) and continental climate varieties. In the palaeogeographic past, in glacial stages, this zone was characterized by great meridional climatic gradient be- 
tween the maritime southern regions and ice-sheets in the north.

Relief of the eastern part of the discussed area, i.e. the East Carpathian Foreland and Podil'ia, has been shaped since the Pliocene. Erosional activity of rivers in the Quaternary resulted in strong dissection of tectonically elevated area. Elongated plateaux are separated by flat-bottomed (East Carpathian Foreland) or canyon-type (Podil'ia) valleys of the Dnister River tributaries. These two regions are connected by the Dnister River main valley. Between Zhuravno and Galich, i.e. on the boundary between the East Carpathian Foreland and Opolian (Opil'ia) region (western part of the Podolian Upland), this valley has transitory features between Subcarpathian and Podolian landscapes; the deeply incised Dnister canyon is typical of the Podil'ia region, and high elevated interfluve surfaces occurring between its right-bank tributaries are typical of the East Carpathian Foreland. Rivers of the Opil'ia region flow in asymmetric valleys with vast flat bottoms. Relief elements of the canyon type are more visible downriver of the Galich basin (Galich Prydnistrov'ia region). In the Podil'ia part, the Dnister River valley represents a typical canyon (Bogucki et al., 2006, 2007).

Many Pleistocene wide step-like terraces separated by distinct scarps are typical landforms of the deeply incised river valleys.

The described morphological conditions were attractive for prehistoric communities irrespective of variable climatic conditions in the Pleistocene. Primitive hunters were especially attracted by good settlement conditions of protruding terrace noses and spurs in river forks (East Carpathian Foreland) as well as hilltop rocks and rock shelters (Podil'ia), which provided them security and were excellent observation points with full view over valley bottoms - natural and rich pastures for animal herds migrating along rivers. Groups of hunters-gatherers located their open seasonal or more stable multi-seasonal camps in these places. Open, multilayer archaeological sites indicate that Palaeolithic communities of different cul- tures appreciated values of such places during many thousands of years.

An additional advantage of the described area was the proximity of exposures of Turonian flint - a good quality material, which was used for making implements during the whole of the Stone Age. Beds of flints occur in Turonian (Cretaceous) limestone exposed in high banks of rivers of the Galich Prydnistrov'ia and Podil'ia regions. Periglacial alluvia could have also been a source of flint occurring among river gravels.

The Silesian-Cracow Upland, mainly the Polish Jura Chain, due to its diversified relief, large number of caves, and access to flint, was an area favourable for settlement in the Palaeolithic but only in those, not numerous in karst area places, where water was abundant, i.e. springs or permanent streams occurred. Most of archaeological findings were discovered in caves and rock shelters. Besides settlements occurring in the well examined southern part of the Polish Jura Chain - Cracow Upland, there are also settlement centres in its central part, i.e. Częstochowa Upland. We include to the discussed set the Biśnik cave - the richest site found in this region.

\section{LOESS SITES AS A SOURCE OF INFORMATION ABOUT PALAOENVIRONMENT}

Among different types of Quaternary sediments, loess, as an aeolian deposit, is characterized by the possibility of continuous accumulation. Formation of loess-soil sequences is closely connected with climatic-environmental changes. Loess dust is formed and deposited most intensively under cold and dry climate conditions, but sometimes these processes occur also in warmer periods (in dry seasons), simultaneously with soil formation. However, such an ideal situation is not common. Even on plateau surfaces, which provide the best conditions for formation of continuous loess sections, deflation of aeolian material or sedimentation breaks in places exposed to wind action occur. Then soils developed during successive soil-form- 
ing processes are superimposed, traces of earlier events are blurred, and the complex history of soil formation is not always possible to examine. Moreover, solifluction processes can develop on gently inclined surfaces of plateau, especially after the phase of pedogenesis.

Different conditions are found on valley sides where different slope processes, synor post-genetic relative to aeolian processes, occur easily. Commonly, numerous stages of their activity are separated by stages of limited redeposition or its lack when soils are formed. As a result, in near-valley loess sections many sedimentation and soil-forming cycles can be found. If we assume that they are controlled by environmental and climatic changes (cold and humid conditions favouring slope processes, stoppage of slope processes in warmer periods favouring plants' development), we can find sections bearing a full record of environmental changes. However, we have to take into consideration that slope processes can be triggered as a result of special local situation, e.g., morphological one, which gives a false effect of climate change.

Palaeoenvironmental reconstructions and stratigraphic interpretation of loess sections are mainly based on field observations: examination of palaeosols and their spatial variability in catenas, observation of sedimentary and post-sedimentary structures, both frost and slope ones ( Lanczont and Boguckyj, 2002). Detailed analyses of selected sections are the next stage of investigations. For the examined Ukrainian sites, the main lithological methods were used: granulometric analysis (areometric and laser - C. Seul, Z. Frankowski), and analysis of typical geochemical components: calcium carbonate, iron oxides and organic matter. The degree of palaeosol development was determined based on chemical analysis of main and trace elements and micromorphological analysis. Oxygen and carbon stable isotope composition of authigenic carbonates provides information about vegetation type and palaeotemperature and precipitation (Łącka et al., 2007, 2009). The most useful are carbonate rhizocretions formed on grass roots, i.e. at a relatively small depth from the palaeosurface. Other carbonate forms, e.g., concretions, formed at greater depth causing difficulties in correlation of isotopic data with the time of loess deposition or soil formation. Pollen analysis for some sites was conducted by M. Komar - a specialist in pollen analysis of clastic deposits (Komar et al., 2009). Moluscan fauna was examined by W.P. Alexandrowicz and R. Dmytruk (Alexandrowicz et al., 2002), and not numerous vertebrate bones were identified by P. Wojtal and G. Lipecki. Thermoluminescence age of deposits was determined by S. Fedorowicz and J. Kusiak. Radiocarbon dating of organic remnants from the Galich site was conducted in the Kiev laboratory. Archaeological investigations were managed by O. Sytnyk and K. Cyrek. The results of these studies were published in many papers (Madeyska, ed. 2002 - including several chapters bearing the results of different detailed investigations; Boguckyj et al., 2001, 2009a,b; Sytnyk et al., 2010, and others).

\section{CAVE SITES AS A SOURCE OF INFORMATION ABOUT PALAEOENVIRONMENT}

The cave interior is protected by rock walls from direct influence of weather conditions, especially in case of large caves, so it favours continuous accumulation of deposits. However, caves are also not easy to study because Palaeolithic cultural materials are often vertically dispersed throughout nearly the whole sedimentary sequence, like in the Biśnik cave, and precise dating of cultural layers is difficult. Cultural layers, which are well developed and contained in thin deposit layer, are rare in caves and often deformed. Recent investigations indicate that a part of material found in cave deposits is often redeposited, like fossil bones, due to natural physical processes occurring in deposit, which represents unsorted mixture of mineral particles with completely different grain sizes. Such processes are empirically evidenced by the differences in radiocarbon 
ages (Lorenc, 2007), chemical composition and state of preservation (Krajcarz, 2009) of fossil bones occurring in the same layer.

The main research method applied to cave deposits is examination of their lithology, especially the features resulting from chemical weathering (indicating warm and humid climatic conditions) and frost weathering (indicating cold and dry conditions) (Hercman et al., 2004; Madeyska, 1981, 2006). The occurrence of different clay minerals also illustrates climatic conditions.

Species composition of animal remains found in cave sediments provides important data about natural environment in cave surroundings. However, the possibility of drawing correct conclusions is influenced by the number of remains and the way of their accumulation (Nadachowski, 1989; Wojtal, 2007). Besides remains of animals living in a cave, we find also those of their preys so the composition of fossil assemblages only partially reflects faunal composition of the past surroundings of the cave. We also have to take into consideration the above-mentioned possibility of redeposition of bone remains in deposit section. Despite these reservations, species composition of fossil faunal assemblages is the source of information about natural environment outside the cave. The degree of bone weathering and diagenesis (determined from the results of histological, micromorphological and chemical analyses) is also an indicator of climatic conditions prevailing in the time when bones were accumulated in a cave, but not yet covered by deposits (Krajcarz, 2009; Krajcarz and Madeyska, 2010). Recently, the studies of so-called molecular fossils have been undertaken, i.e. determination of plant biomarkers being a source of information about the origin of organic material in deposits. We can deduce that this material originated from decomposition of grass, needles or leaves from the content of different $n$-alkanes (Krajcarz et al., 2010). This method can provide information about the changes of past vegetation occurring in deposits, and thus help to reconstruct climatic changes during sedimentation. Furthermore, occur- rence of different zoosterols indicates that organic material originated from herbivores, carnivores or man (Krajcarz, 2009).

\section{TRAVERTINE SITES AS A SOURCE OF INFORMATION ABOUT PALAOENVIRONMENT}

Another kind of Palaeolithic sites are those occurring in travertine mounds. Several sites of this type occur in Slovakian Spiš (Kaminská, 1998). Despite the fact that they are situated outside the studied peri- and meta-Carpathian zones, they are included in this study owing to geographically close occurrence and analogies of archaeological materials. As indicated by examination of currently forming travertine in this region, they were associated with warm springs (Gąsiorowski et al., 2010), which were undoubtedly attractive for Palaeolithic people. Chronostratigraphic information is based on travertine dating using U-Th method (Ford, 1995). Pollen analysis, quite difficult in such deposits, provides data about palaeovegetation.

\section{EXAMINED SITES (SITUATION, DESCRIPTION, SECTIONS)}

The following most important Palaeolithic sites investigated in the last years were selected for our study: Ukrainian sites - Velykyj Glybochok situated in Podil'ia (Ternopil Upland), Yezupil and Galich situated on the Dnister River in the so-called Galich Prydnistrov'ia region (on the borderland between the East Carpathian Foreland and Podil'ia Upland), Polish sites - Biśnik cave in the Silesian-Cracow Upland, and Obłazowa cave in the Podhale region. Information about other, earlier examined sites situated in the described area was also included.

Velykyj Glybochok (Hluboczek Wielki) site has been investigated since the 1980s. It is situated on the right bank of the Seret River, near Ternopil in Podil'ia, in the Miodobory (Tovtry) range, in the sedimentary cover of Neogene reef limestone exploited in 
a large quarry. This cover consists of loess deposits with fossil soils. Loess partially fills ragged karstified bedrock. The section is preserved only fragmentarily as a result of intensive slope processes in the Pleistocene (evidenced by huge debris-solifluction covers in deposit sequence) and recent de- struction during limestone exploitation. Palaeoenvironmental interpretation is based on examination of fossil soils and molluscan assemblage composition (Boguckyj et al., 2009a; Boguckyj and Dmytruk, 2003).

A fossil soil of forest type (with features of cambisol), occurring directly on weath-

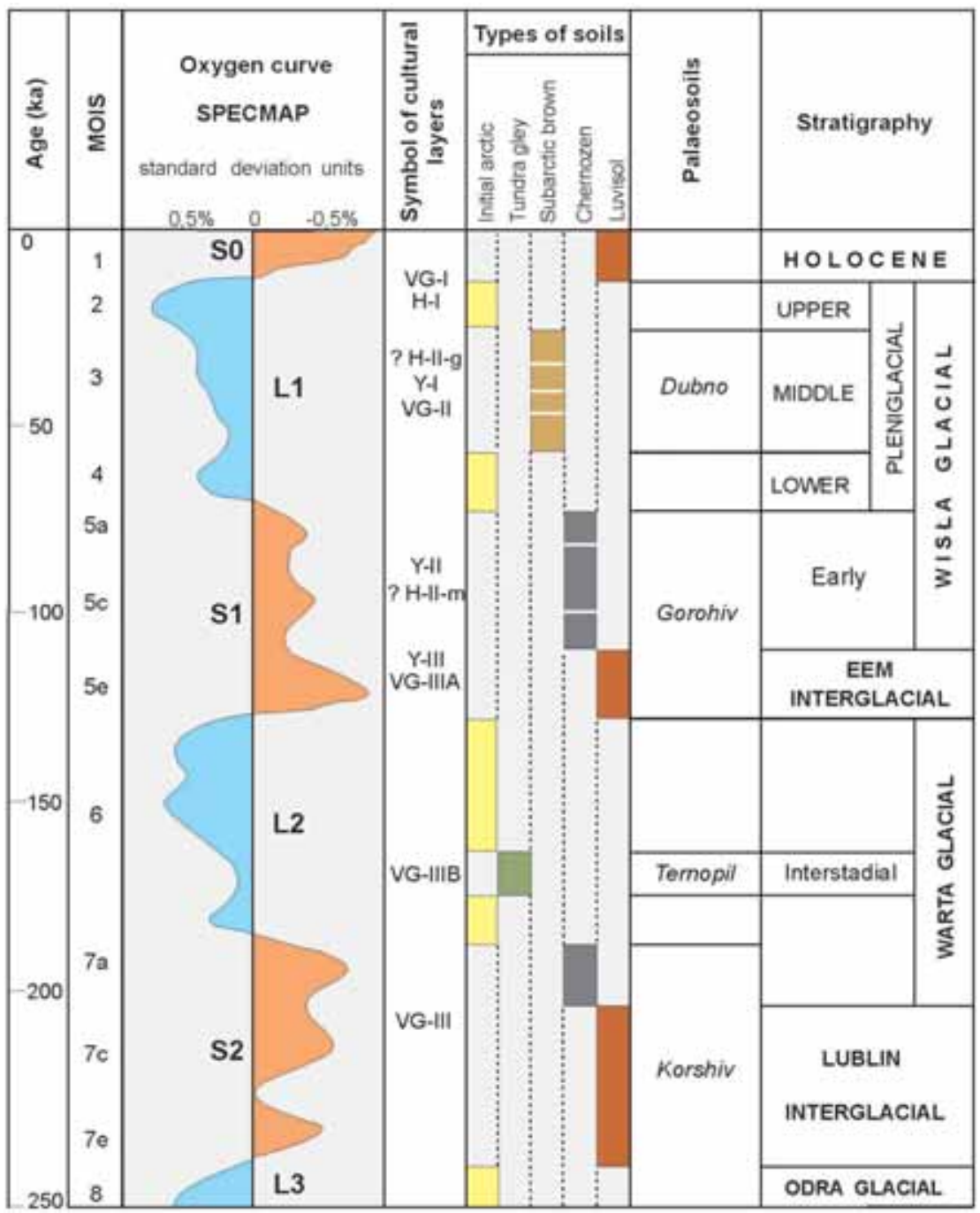

Figure 2. Scheme of the fossil soils and cultural horizons chronology of the main West-Ukrainian loess sites: Y - Yezupil, H - Galich, VG - Velykyj Glybochok

MOIS - Marine Oxygen Isotope Stages, SO, S2, S3 - fossil soils, L1, L2, L3 - loess horizons, VG-III - Late Acheulian with Levalloisian technique, VG-IIIB, VG-III A and Y-III - Mousterian with Levalloisian technique, Y-II and H-IIm(?) - Micoquian, VG-II, Y-I - Upper Palaeolithic, H-IIg (?) - Gravettian, H-I - Epigravettian, VG-I - Final Palaeolithic 
ered limestone, its residuum or loess, is correlated with the Korshiv soil (S2) described from other loess sections in Podil'ia (Fig. 2) and dated to the penultimate interglacial (MOIS 7, Fig. 3). The Middle Palaeolithic artefact assemblage (cultural layer HV III) found in this soil is defined as initial Levallois. It is characterized by medium rate of facetting and absence of bifacial forms (Sytnyk et al., 2010). Cultural layer HV III of similar nature occurs above, in solifluction series covering the intraloess (i.e. L2) Ternopil horizon of weakly developed initial cambisol, which originated during a short period favourable for open landscape vegetation. Molluscs living in open habitats prevail.

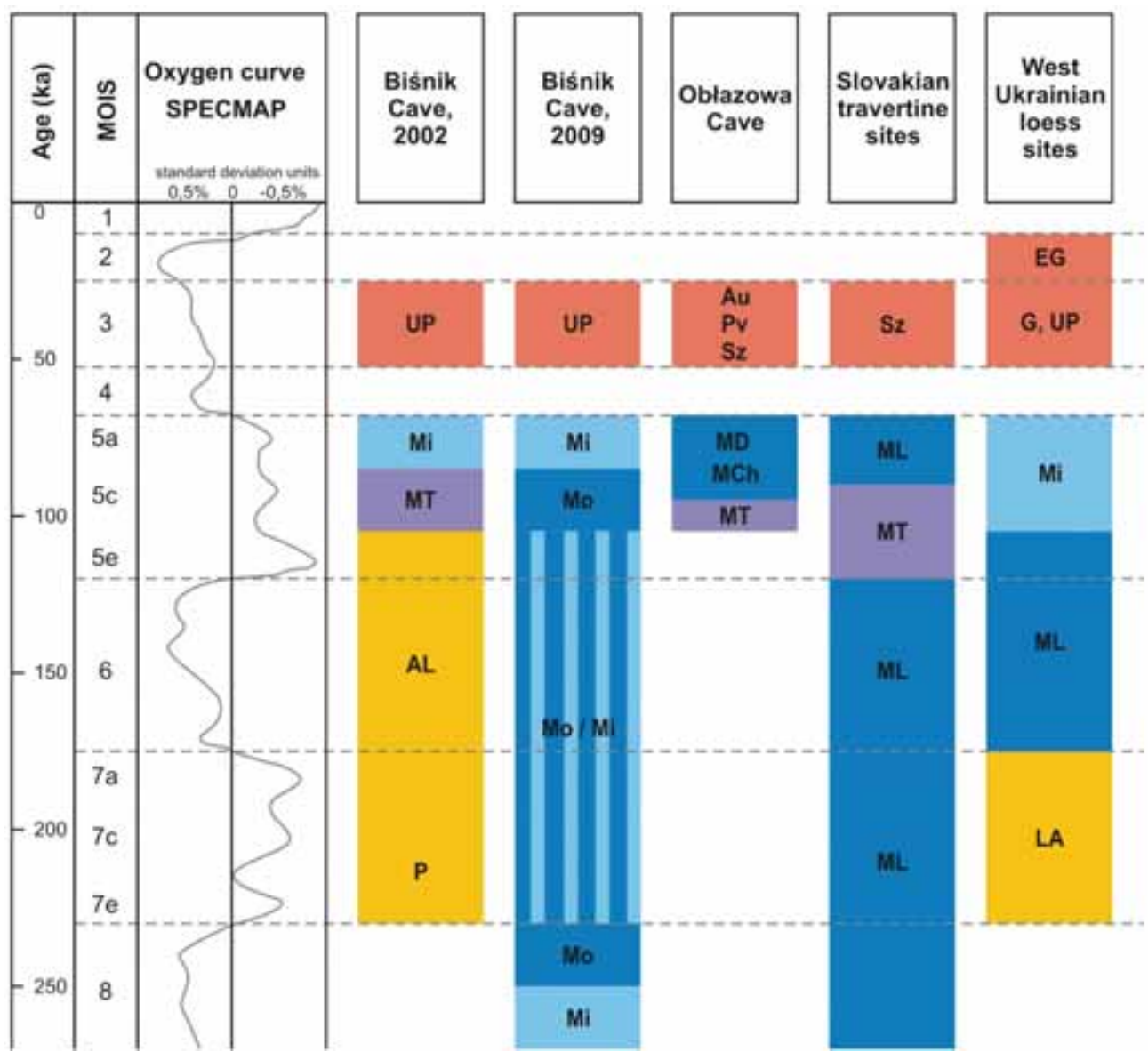

Figure 3. Chronology of the peri-/meta-Carpathian and the Carpathian Palaeolithic

Biśnik Cave 2002 - according to Cyrek ed. (2002); Biśnik Cave 2009 - according to Cyrek et al. (2009a,b); Obłazowa Cave - according to Valde-Nowak et al., eds. (2003), Slovakian travertine sites (Hôrka-Ondrej and others) - according to Káminska (1998, 2000), West Ukrainian loess sites - according to Boguckyj et al. (2001), Sytnyk and Boguckyj (1998), Sytnyk et al. (2009, 2010).

Explanations: P - Piekary-type elements, AL - Acheulean with Levalloisian elements, MT - „Taubachien”, Mo Mousterian, ML - Mousterian with Levalloisian technique, MD - denticular Mousterian, MCh - Charentian, Mi - Micoquian, LA- Late Acheulian with Levalloisian technique, UP - Upper Palaeolithic, Au - Aurignacian, Pv - Pavlovian, Sz - Szeletian, G - Gravettian, EG - Epigravettian 
A Levallois-Mousterian artefact assemblage was found in the Gorohiv pedocomplex (S1) (partially redeposited on slope and correlated with the Eemian interglacial and Early Vistulian $=$ Weichselian Glacial, i.e. MOIS 5) and in the overlying solifluction series with limestone boulders. This soil was initially bipartite luvisol evidencing forest vegetation development. In redeposited remnants of the interstadial Dubno soil (MOIS 3), which are superimposed on the luvisol, not numerous Upper Palaeolithic artefacts (HV II) with some Aurignacian features were found. The occurrence of molluscs typical of open habitats indicates cold and dry climatic conditions. The final Palaeolithic Świder-like complex (HV I) was found in the bottom part of the Holocene soil (S0).

Yezupil (Jezupol) site is situated on a Pleistocene loess terrace of the Dnister River, near the mouth of its tributary, Bystrycja River, and near Galich town. The site has been investigated since the 1990s (Boguckyj et al., 2001; Madeyska ed., 2002). Lithological, geochemical, micromorphological, palaeomagnetic, petromagnetic, and palynological analyses were conducted (Boguckyj et al., 2001; Komar, 2002; Komar et al., 2009). Alluvia of the Dnister River are covered by about $10 \mathrm{~m}$ thick loess containing the Eemian-Early Glacial Gorohiv pedocomplex: a well-developed interglacial soil of luvisol type with superimposed chernozem (MOIS 5). The overlying loess series (L1) contains the Dubno interstadial soil from the middle part of the Plenivistulian.

In the light of pollen analyses, the Eemian succession (boreal forest, mixed forest, rich mixed forest) was followed by the Early Glacial thin boreal forest and open forest. Vegetation of open landscape with patches of trees developed during the Lower Plenivistulian (MOIS 4). During the time of the Dubno soil development, of cambisol type, proportion of coniferous trees increased and admixture of deciduous trees was small. Occurrence of sedge and moss vegetation indicates wet habitat. The malacofauna in this horizon contains forms typical of open dry habitat. Based on these results we can con- clude that a mosaic of wet and dry habitats occurred in cold climate of this interstadial.

Uniqueness of this site consists in the fact that artefacts of the Levallois-Mousterian culture were found in situ, in clear stratigraphic position, i.e. in eluvial horizon of the Eemian soil. Over the Gorohiv pedocomplex, in a solifluction horizon (composed of material from chernozem soil), a cultural layer with bifacial tools typical of Micoquian-Prądnik culture was found. Not numerous and not typical Upper Palaeolithic flint artefacts were found in the Dubno soil.

Galich (Halicz) site is characterized by occurrence of several geological sections representing a long part of the Pleistocene (at least from the Oka=San 2 Glacial to Vistulian, i.e. MOIS 12 - MOIS 2). Sections occurring in the protruding toward the Dnister River part of this terrace, near the mouth of the Lukva River, are exposed in an high valley-side and in excavation of the abandoned brick-yard. The thickness of loess deposits reaches $50 \mathrm{~m}$. The Palaeolithic site Galich I, occurring in the highest position, has been studied since the 1990s. Several cultural layers occur in the Upper Vistulian loess (L1) both under and within initial gley soil (so-called Rivne horizon) together with mammoth bones (Wojtal, 2001). These settlement phases represent the Epigravettian Culture or the East-European variety of the Gravettian Culture (Cyrek and Sytnyk, 2002). Poor pollen spectrum contains mostly herb pollen and single pollen grains of pine and shrubs. Shadow-loving species prevail in malacofauna composition, but some mesophilous and higrophilous ones were also present (Alexandrowicz et al., 2002).

Older cultural materials - mixed artefacts of the Middle and Upper Palaeolithic type - were discovered during geological investigations of other sections representing older Vistulian loess deposits in the Galich II site in 2002. Investigations carried out in the following years indicated that these materials were redeposited because they occur in solifluction deposits filling a small buried valley (Galich II section). Only a small part does occur in a more clear stratigraphic position, 
on partially eroded Eemian soil and in thin solifluction layers over the Early Vistulian soils (Galich IIa section). Based on collected data, we suppose that these are two separate assemblages: the Middle Palaeolithic with Micoquian Culture features in the Gorochiv pedocomplex, and the Upper Palaeolithic with features of the Early Gravettian Culture (Bogucki et al., 2009 b; Sytnyk et al., 2009). However, considerable redeposition made it impossible for us to determine the exact stratigraphic position of both assemblages and primary position of cultural layers, as well as to describe the environment.

Biśnik Cave in Smoleń near Pilica has been investigated for 20 years by a team of specialists (archaeologists, geologists and palaeontologists) with Professor K. Cyrek at its head. The results of the first ten years of investigations are published in a monograph (Cyrek, 2002), and from the next years in synthetic papers (Cyrek et al., 2009 a; Cyrek, 2010; Cyrek and Sudoł, 2010). An over 5-m-thick section examined in the cave contains Quaternary deposits accumulated during a long period of time: from the Odra Glacial to the Holocene i.e. MOIS 8 - MOIS 1 . Deposits occurring near the cave bottom are probably of Pliocene age. Stratigraphy was determined based on lithology of deposits and variability of faunal composition, mostly ecological preferences of identified vertebrate species (Mirosław-Grabowska, 2002; Cyrek et al., 2009 b; Socha, 2009; Stefaniak and Marciszak, 2009). Faunal composition in the Biśnik Cave is not very variable throughout the section. Forest, steppe, and tundra species, besides euryoecious and aquatic ones, were found in all layers. Quantitative proportions between the number of species (belonging to separate ecological groups) and individuals changed from 10 to $30 \%$ in separate layers. Based on these data, stratigraphic interpretation was possible to make. However, new data will be obtained with time, and interpretation will be probably modified. The age of the bottom part of Quaternary sediments overlying the Pliocene ones was not determined precisely because individual layers are thin and discontinuous.
Artefacts were found in almost all geological layers. They do not form distinct cultural layers, but are scattered at different depths. Interpretation of cultural material was changed because new data were obtained with time. In 2002 K. Cyrek described material from the Eemian interglacial and older deposits as late Acheulian with Levalloisian and Clactonian elements, similar to the Piekary-type material. Artefacts dated to the Early Vistulian were described as Taubachian, and younger ones were classified as Micoquian. The Upper Palaeolithic materials found in sediments from the Younger Plenivistulian were called „Jerzmanovician?”. In the later papers, K. Cyrek distinguished (Cyrek et al., 2009 a, b) one Upper Palaeolithic cultural layer, 13 Middle Palaeolithic assemblages with 17 units of lower rank (horizons) related to the Mousterian or Levalloisian-Mousterian and Micoquian cultures/industries. Particular units were also characterized by techniques of flint working (Cyrek et al., 2009 b; Cyrek and Sudol, 2010): Levalloisian, flake, Mousterian, and blade techniques. In the older part of deposits, up to the Eemian interglacial inclusive, tools assigned to Mousterian and Micoquian techniques occurred together in almost all geological horizons, and in some horizons the existence of denticulate forms of tools was described. The problem of dating sediments older than MOIS 5e is not solved definitively till now. Materials from the older part of younger deposits (corresponding to MOIS $5 \mathrm{~d}-\mathrm{a}$, and MOIS 4) were described as Levalloisian-Mousterian, and those from their younger part - as Micoquian (Fig. 3).

Obtazowa Cave is situated in the south-western part of Obłazowa Skała klippe, in the western part of the Pieniny Klippen Belt. It has been investigated since 1985 by a team of specialists with P. Valde-Nowak (archaeologist) and A. Nadachowski (zoologist) at its heads. This small cave is the only multilayer site of the Upper and Middle Palaeolithic in the Carpathian Mts. The excavations were carried out very thoroughly: all investigated deposits were washed 
through a sieve and very rich archaeological and palaeontological material was obtained (Valde-Nowak et al., eds., 2003). The section is composed of alluvial gravels of the pre-Białka River at the bottom, covered by loamy-debris deposits of a dry cave. The degree of debris weathering is less variable compared to cave deposits of the Silesian-Cracow Upland. Faunal composition is also less variable. Tundra and cold steppe species prevail. However, two series of sediments formed in warmer climate, separated by sediments of a cold phase, were distinguished. Variability of deposits and fauna composition (proportions between the number of species and individuals connected with different biotopes), between particular layers correlated with the Early Vistulian - MOIS 5a-d (layers XIX-XIII) and Interplenivistulian - MOIS 3 (layers XI-VIII) is so weak that it is impossible to distinguish lower-rank climatostratigraphic units. Mammals, birds and mollusks found in older series (Early Vistulian) are mostly forest species and those which required at least single trees growing in meadows, so they indicate temperate climate. Admixture of species connected with tundra and steppe environment is also found and indicates temporary climatic cooling. Species connected with water environment (birds, fishes, amphibians) are more numerous in the younger series (Interplenivistulian). In the highest part of the section (Last Glacial Maximum - MOIS 2), devoid of archaeological material, debris is weakly weathered. It is covered by several waste fans with mixed fauna of the Late Glacial and Holocene.

In the older part of debris-loamy series (layers XIX-XIII), six Mousterian horizons were discovered, the oldest of which directly overlies alluvial gravels. P. Valde-Nowak correlates them with different variants of the Mousterian culture. The assemblages from layers XIX, XVII and XVI represent Taubachien. One cultural layer $(\mathrm{XVb})$ is connected with the so-called South-East Charentian, and artefacts from layer XIII represent a variant with denticulate tools of the Mousterian culture.
The younger series of deposits (layers XI-VIII), containing Upper Palaeolithic materials, is separated from the underlying warm series by layer XII accumulated in cold climate of the Lower Plenivistulian, as indicated by its lithology and predominance of lemmings among rodents. The Szeletian leaf points' complex was found in layer XI. Unique assemblage of the Upper Palaeolithic Pavlov Culture (Early Gravettian), found in layer VIII on platform in the entrance to the cave, contains the following artefacts: an object in the shape of boomerang made of mammoth tusk, which was dated to 28-30 thousand years ago, objects made of arctic fox teeth and shells, and man finger bones. This assemblage is considered as the remains of Palaeolithic man sanctuary.

Hôrka-Ondrej is one of several Palaeolithic sites situated in travertine mounds in the Slovak Spiš region (near the southern slopes of the Tatra Mts). It was investigated in the last decade of the 20th century (Ford, 1995; Kaminská, 1998, 2000). Most travertine sites contain traces of settlement from the Eemian interglacial (middle part of the Middle Palaeolithic), several assemblages are older (early phase of the Middle Palaeolithic), and there are also some from warmer phases of the penultimate glacial (MOIS 6) and even from the penultimate interglacial (MOIS 7). Middle Palaeolithic artefacts from the beginning of the Vistulian were also found. Materials typical of a younger phase of Levalloisian technique were found at Hôrka-Ondrej and Vyšne Ružbachy sites, and those of Mousterian with Levalloisian technique at Beharovce-Sobotisko site. Gánovce site is the known place bearing artefacts from the middle phase of the Middle Palaeolithic. A cranium cast of the Neanderthal man was found at this site. Assemblages of microlithic Taubachien were found at Hôrka-Ondrej and Gánovce-Hrádok sites. The youngest phase of the Middle Palaeolithic is represented by the Mousterian assemblage of quartz and radiolarite objects characterized by the Levalloisian technique (Hôrka-Ondrej site). 


\section{COMPARISON-CORRELATION}

As it was presented above, each site provides much information concerning environment and age of particular stages of the Palaeolithic settlement. However, each site presents problems difficult to solve. Comparison of data gathered at different sites and chronostratigraphic interpretation permit us to obtain a more complete picture of settlement history. It is very important in the case of Palaeolithic sites, which are not numerous compared to the sites dating from later ages.

Environmental reconstructions usually give a picture of co-occurrence of different biotopes, different vegetation types, animals with different environmental preferences. By analogy with modern times, we can infer that vegetation in the examined areas in the past, both in warm and cold periods, was also a mosaic of different communities depending on the substratum, soils and mesoclimatic (topoclimatic) conditions. However, information about the past obtained from the studied sections should be interpreted taking into consideration the rate of climatic changes occurring in younger Pleistocene time. Analyses of oxygen stable isotope composition, e.g., in ice cores drilled in Greenland, point to rapid changes of temperature occurring in many intervals of the Pleistocene, which were characterized by similar amplitude and frequency as those in the Late Glacial. Therefore, as cave deposits accumulated very slowly (several centimetres per millennium), we obtain a picture of environment composed of overlapping data concerning periods typified by different climate.

Fossil soils in loess sites often represent long periods of time (i.e., interglacials), they are effect of overlapping of different pedogenetic processes and blurring of earlier ones, generally due to temperature and moisture changes. Fossil soils representing short periods of pedogenesis (i.e., interstadials) could be preserved only when aeolian or slope deposition formed layers separating soils.

Correlation presented in Fig. 3 is based on interpretation of sequence of environmental changes. Numerous TL dating re- sults available for the investigated sections are not presented. However, these results were taken into consideration.

Chronostratigraphic extents of individual cultural units from selected sites and their correlation are presented in Fig. 3. Chronology is based on oxygen-isotope stratigraphy as an objective picture of climatic changes with time. However, determination of artefacts' age is not always reliable. The extents are presented as continuous despite the fact that cultural layers are mostly traces of short-lasting settlement or hunters' camps, so they represent short episodes separated by periods of natural sedimentation and also of deposit destruction.

\section{FINAL REMARKS}

Investigations of Palaeolithic sites in the Podil'ia and Prydnistrov'ia regions proved that settlement existed from the penultimate interglacial to the end of the last glacial, i.e., in the time correlated with MOIS 7 - MOIS 2. Materials from the Biśnik cave represent similar period but there are premises that Middle Palaeolithic settlement started considerably earlier (Cyrek et al., 2009 a, b). Chronology of deposits from this cave is not definitively explained, so we have to wait for the results of further investigations.

We present names of cultural units after original archaeological publications. Archaeological terminology is not established, and even such terms as culture, industry, technique or assemblage are used in different meaning by different authors. In Fig. 3, the authors (earth scientists) marked related units with the same colours in an attempt to understand archaeological interpretation

The purpose of this paper was to summarize the actual state of research on natural aspects of history of prehistoric settlement in the peri- and meta-Carpathian zones. This is also one of the first steps in accomplishment of a project funded by the Ministry of Science and Education (691/N - Ukraina 2010/0) "Palaeolithic oecumene of peri- and meta-Carpathian zones - study of environmental 
changes in western Ukraine and south-eastern Poland in the Pleistocene and their influence on prehistoric settlement and migration routes (based on loess and cave sites)".

\section{REFERENCES}

Alexandrowicz, W.P., Boguckyj, A., Dmytruk, R. and Łanczont, M. (2002), Malakofauna lessów Naddniestrza halickiego [Molluscs of loess deposits in the Halyč Prydnistrov'ja region], in Madeyska, T. (ed.), Lessy i paleolit Naddniestrza halickiego (Ukraina) [Loess and Palaeolithic of the Dniester River basin, Halič region (Ukraine)], Studia Geologica Polonica, 119: 253-290.

(Bogucki) Boguckyi, A. and Dmytruk, R. (2003), Reconstruction of paleontological and geographical conditions of creating of the loess and palaeosol of the multi-layer paleolithic site Velykyi Glybochok (on the basis of the molluscan fauna), in: Zbirnik naukovyi: The role of protected areas of the Western Podillia and Jura of Ojców in preservation of biological and landscape diversity, Grimajliv-Ternopil', Lileja, pp. 133-142 [in Ukrainian with English summary].

Bogucki, A., Łanczont, M. and Wojtanowicz, J. (1999), Problems of the Quaternary stratigraphy and paleogeography in the San and Dniester interfluve (Poland and Ukraine borderland), Quaternary Studies in Poland, 16: 3-14.

(Bogucki) Boguckyj, A., Cyrek, K., Konecka-Betley, K., Łanczont, M., Madeyska, T., Nawrocki, J. and Sytnyk, O. (2001), Palaeolithic loess-site Yezupil on Dnister (Ukraine) - stratigraphy, environment and cultures. Studia Quaternaria, 18: 25-46.

(Bogucki ) Boguckyj, A., Łanczont, M. and Yacyszyn, A. (2006), Gtówne paleogeograficzne etapy rozwoju doliny górnego i środkowego Dniestru [Main palaeogeographic stages of development of the Upper and Middle Dniester Valley], in Zawada, K. (ed.) Konferencja Międzynarodowa IV. Świętokrzyskie spotkania geologiczno-geomorfologiczne, Regionalne aspekty funkcjonowania systemów dolinnych [The International Conference: 4th Świętokrzyskie geological-geomorphological meeting on regional aspects of the valley sys- tems development], Akademia Świętokrzyska, Jodłowy Dwór-Kielce, pp. 18-21.

(Bogucki) Boguckyj, A., Dmitruk, D., Łanczont, M., Madeyska, T. and Yacyszyn, A. (2007), Paleogeograficzne uwarunkowania współczesnych krajobrazów w dolinie środkowego Dniestru [The palaeogeographic base of contemporary landscapes in the Middle Dniester Valley], Prace Komisji Krajobrazu Kulturowego PTG, 7, UŚ, Sosnowiec: 191-201.

(Bogucki) Boguckyj, A., Łanczont, M., Łącka, B., Madeyska, T. and Sytnyk O. (2009a), Age and the palaeoenvironment of the West Ukrainian Palaeolithic: the case of Velykyi Glybochok multi-cultural site, Journal of Archaeological Science, 36: 1376-1389.

(Bogucki) Boguckij, A., Lanczont, M., Sytnyk, O. Madeyska, T., Kusiak, J., Fedorowicz, S., Dmytruk, R., Jacyszyn, A., Dumas, I. and Holub, B. (2009b), Paleolitychna stoyanka Halich II: problemy stratygrafii i khronologii [Palaeolithic site Galich II: problems of stratigraphy and chronology], in: Materialy $i$ doslidzennia $z$ archeologii Prykarpatt'ia $i$ Volhyni,1, Lviv: 17-46.

Cyrek, K. (2002), Jaskinia Biśnik. Rekonstrukcja zasiedlenia jaskini na tle zmian środowiska przyrodniczego [Reconstruction of the Biśnik Cave settlement against a background of natural environment changes], Wydawnictwo Uniwersytetu Mikołaja Kopernika, Toruń: 231 pp.

Cyrek, K. (2010), The Biśnik Cave in Southern Poland: reconstruction of the Palaeolithic cave habitation in relation to the environmental changes, in Burdukiewicz, M. and Wiśniewski, A. (eds.), Middle Palaeolithic Human Activity and Palaeoecology; New Discoveries and Ideas, Wrocław: 69-94

Cyrek, K. and Sudol, M. (2010), Zmiany w zasiedleniu Jaskini Biśnik w plejstocenie [Changes in the inhabitation of the Biśnik Cave during the Pleistocene, Annales UMCS, section. B, LXV, 2, Lublin: 57-68.

Cyrek, K. and Sytnyk, O. (2002), Paleolit Naddniestrza halickiego [Palaeolithic of Halič region], in Madeyska, T. (ed.), Lessy i paleolit Naddniestrza halickiego (Ukraina) [Loess and Palaeolithic of the Dniester River basin, Halič region (Ukraine)], Studia Geologica Polonica, 119: 293-314. 
Cyrek, K., Socha, P., Stefaniak, K., Madeyska, T., Mirosław-Grabowska, J., Sudoł, M. and Czyżewski Ł. (2009a), Palaeolithic of Biśnik Cave (Southern Poland) within the environmental background, Quaternary International, 220: $5-30$

Cyrek, K., Mirosław-Grabowska, J., Stefaniak, K. and Socha, P. (2009b), Archaeology, stratigraphy and palaeoecology of the Biśnik Cave, in Stefaniak, K, Tyc, A. and Socha, P. (eds.), Karst of the Częstochowa Upland and of the Eastern Sudetes - palaeoenvironments and protection, Studies of the Faculty of Earth Sciences University of Silesia, 56, SosnowiecWrocław: 191-214.

Ford, D.C. (1995), U series dating of the Hôrka travertine Samales, in Kovanda, J., Smolikova, L., Ford, D.C., Kaminská, L., Ložek, V. and Horáček I. (eds.), The Skalka travertine mound at Hôrka-Ondrej near Poprad (Slovakia), Antropozoikum 22: 126-128.

Gąsiorowski, M., Hercman, H., Gradziński, M., Smosna, P., Czop, M. and Motyka, J. (2010), Geochemical and climatic parameters of environment versus isotopic composition of travertine in Northern Slovakia. XIX Congress of the Carpathian-Balkan Geological Association, Abstracts volume, Geologica Balcanica, 39 (1-2), Sofia: 122-122.

Hercman, H., Mirosław-Grabowska, J. and Madeyska, T. (2004), Zapis zmian środowiska ostatnich 150000 lat $w$ osadach jaskiń Wyżyny Krakowsko-Częstochowskiej [Record of the environment changes during the last 150000 years in cave sediments of the Kraków-Częstochowa Upland], in Partyka, J. (ed.), Zróżnicowanie $i$ przemiany środowiska przyrodniczo-kulturowego Wyżyny Krakowsko-Częstochowskiej, tom I, Przyroda [Diversity and changes of natural-cultural environment of the Cracow-Częstochowa Upland, volume I, Nature], Ojcowski Park Narodowy, Ojców: 83-88.

Kaminská, L. (1998), Hôrka-Ondrej. Osídlenie spišských travertínov v staršej dobe kamiennej [Hôrka-Ondrej. Settlement of Spiš travertine in older Stone Age], Archeologické pamätky Slovenska, Košice 2005: 145 pp.

Kaminská, L., (2000). Hôrka-Ondrej. Research of a Middle Palaeolithic travertine locality. Insti- tute of Archaeology of the Slovak Academy of Sciences, Nitra: 202 pp.

Komar, M. (2002). Analiza pyłkowa górnoplejstoceńskich lessów i gleb kopalnych stanowisk Yezupil i Halyč [Pollen analysis of the Upper Pleistocene loesses and paleosols at Yezupil and Halyč sites], in Madeyska, T. (ed.), Lessy i paleolit Naddniestrza halickiego (Ukraina) [Loess and Palaeolithic of the Dniester River basin, Halič region (Ukraine)], Studia Geologica Polonica, 119: 243-249.

Komar, M., Łanczont, M. and Madeyska, T. (2009). Pollen record of vegetation spatial pattern in the loess zone between the Dnieper and Odra rivers during the last interglacial-glacial cycle (5-2 OIS), Quaternary International, 198: 152-192.

Krajcarz, M. (2009), Rekonstrukcja środowiska sedymentacji $i$ diagenezy plejstoceńskich osadów i szczątków kostnych zjaskini Biśnik (Jura Polska) na podstawie badań geochemicznych [Reconstruction of environment and diagenesis of sedimensts and fossil bones from the Biśnik cave (Polish Jura) on the base of geochemical researches], Unpublished $\mathrm{PhD}$ thesis, Faculty of Geology, University of Warsaw.

Krajcarz, M.T., Gola, M.R. and Cyrek, K.J. (2010), Preliminary suggestions on the Pleistocene palaeovegetation around the Biśnik Cave (Częstochowa Upland, Poland) based on studies of molecular fossils from cave sediments, Studia Quaternaria, 27: 55-61.

Krajcarz, M. and Madeyska,T. (2010), Application of the weathering parameters of bones to stratigraphical interpretation of the sediments from two caves (Deszczowa Cave and Nietoperzowa Cave, Kraków-Częstochowa Upland, Poland), Studia Quaternaria, 27: 43-54.

Lorenc, M. (2007), Rekonstrukcja paleotemperatur Vistulianu na podstawie zespołów kopalnych ptaków [Reconstruction of Vistulian paleotemperature on the base of assemblages of fossil birds], Wydawnictwo Naukowe UAM, Poznań: 168 pp.

Łanczont, M. and (Bogucki) Boguckyj, A. (2002), Badane profile lessowe i stanowiska paleolityczne Naddniestrza halickiego [The examined loess sites in the Halyč Prydnistrov'ja region], in Madeyska, T. (ed.), Lessy i paleolit Naddniestrza halickiego (Ukraina) [Loess and 
Palaeolithic of the Dniester River basin, Halič region (Ukraine)], Studia Geologica Polonica, 119: 33-182.

Łącka, B., Łanczont, M. and Madeyska, T. (2007), Formy morfologiczne autogenicznych węglanów i ich skład izotopowy (trwałe izotopy węgla i tlenu) w lessach Podkarpacia i Podola [Morphological forms of authigenic carbonates and their isotopic composition (stable isotopes of carbon and oxygen) in loess profiles at the Carpathian Margin and Podolia], Annales UMCS, section. B, Lublin: 93-112.

Łącka, B., Łanczont, M. and Madeyska, T. (2009), Oxygen and carbon stable isotope composition of authigenic carbonates in loess sequences at the Carpathian margin and Podolia, as palaeoclimatic record, Quaternary International, 198: 136-151.

Madeyska, T. (1981), Środowisko człowieka w środkowym i górnym paleolicie na ziemiach polskich w świetle badań geologicznych [Natural environment of human in the Middle and Upper Palaeolithic in Poland in the light of geological research], Studia Geologica Polonica, 69: 124 pp.

Madeyska, T. (ed). 2002. Lessy i paleolit Naddniestrza halickiego (Ukraina). [Loess and Palaeolithic of the Dniester River basin, Halič region (Ukraine)], Studia Geologica Polonica, 119: 1-389.

Madeyska, T. (2006), Tto przyrodnicze osadnictwa pradziejowego Jury Ojcowskiej [Natural background of the Palaeolithic occupation in the Ojców Jura region], in Lech, J. and Partyka J. (eds.), Jura Ojcowska w pradziejach $i$ w poczatkach państwa polskiego [The Ojców Jura in prehistory and in the beginning of the Polish state], Wydawnictwo Ojcowskiego Parku Narodowego: 270-312.

Mirosław-Grabowska, J. (2002), Litologia i stratygrafia osadów jaskini Biśnik [Lithology and stratigraphy of Biśnik cave deposits], in Cyrek, K. (ed), Jaskinia Biśnik. Rekonstrukcja zasiedlenia jaskini na tle zmian środowiska przyrodniczego [Biśnik Cave. Reconstruction of the inhabitation of the cave against a background of natura environmental changes], Uniwersytet Mikołaja Kopernika, Toruń: 143-180.

Nadachowski, A. (1989), Origin and history of the present rodent fauna in Poland based on fossil evidence, Acta Theriologica, 34(2): 37-53.
Socha, P. (2009), Small mammals (Erinaceomorpha, Soricomorpha, Chiroptera, Lagomorpha, Rodentia) from pleistocene sediments of the Biśnik Cave, in Stefaniak, K., Tyc, A. and Socha, P. (eds.), Karst of the Częstochowa Upland and of the Eastern Sudetes - palaeoenvironments and protection, Studies of the Faculty of Earth Sciences University of Silesia, 56, Sosnowiec-Wrocław: 215-224.

Stefaniak, K. and Marciszak, A. (2009), Large mammals (Carnivora, Ungulata) from Pleistocene sediments of the Biśnik Cave, in Stefaniak, K, Tyc, A. and Socha, P. (eds), Karst of the Częstochowa Upland and of the Eastern Sudetes - palaeoenvironments and protection, Studies of the Faculty of Earth Sciences University of Silesia, 56, Sosnowiec-Wrocław: 225-254.

Sytnyk, O. and (Bogucki) Bogutskyi, A. (1998), Palaeolithic of Podillya: Velykyi Glybochok I, National Ukrainian Academy of Science, Lviv, 143 pp.

Sytnyk, O., (Bogucki) Boguckyj, A., Lanczont, M. and Madeyska, T. (2010), Dniesterian Mousterian from the Velykyi Glybochok site related to palaeoenvironmental changes, Quaternary International, 220: 31-46.

Sytnyk, O., Koropeckyj, R., Boguckij, A., Lanczont, M. and Madeyska, T. (2009),Tekhniko-typologichnyj analiz arkheologichnykh materialiv z paleolitychnoi stoyanky Halych II [Technical-typological analysis of archaeological materials from the Palaeolithic Halych II site], Materialy $i$ doslidzennia $z$ arkheologii Prykarpatt'ia i Volhyni, 1, Lviv: 47-73.

Valde-Nowak, P, Nadachowski, A. and Madeyska, T. (eds.), (2003), Obtazowa cave - human activity, stratigraphy and palaeoenvironment, Institute of Archeology and Ethnology, Polish Academy of Sciences, Kraków: 176 pp.

Wojtal, P.( 2001), The new Upper Palaeolithic mammonth site at Halich (Ukraine), Acta Zoologica Cracoviensia, 44, 2: 137-142.

Wojtal, P. (2007), Zooarchaeological studies of the Late Pleistocene sites in Poland, Institute of Systematics and Evolution of Animals PAS, Kraków: 189 pp.

Paper first received: March 2011

In final form: May 2011 